brushing is insufficient to produce sound, still they may move the charcoal sufficiently to produce alternations of current, each of which may be able to set up vibrations in the telephone plate in its own period, or a modification of it, giving what I call the jarring sound. If, therefore, we have this sound, we know that either the microphone is exposed to sounds so loud as to produce complete break of contact, or that there is a motion going on affecting it, of insufficient rapidity to be audible.

With the object of reproducing the voice or musical notes, I have made the following modification of the instrument:-A ferrotype plate 3 inches in diameter is fastened over a hole $2 \frac{1}{2}$ inches in diameter in a thick piece of wood; a flat piece of gas carbon weighing a few grains and having a fine copper wire attached to it is fastened to the top of the plate in the centre; over the piece of carbon is suspended by a wire spring another piece of carbon finely pointed, weighing about $\frac{1}{4} \mathrm{oz}$, and adjusted so as just to touch the carbon plate. The current is then led by the wires through the carbon point, and by careful adjustment of the latter almost any degree of sensitiveness can be attained. Whenever the sound becomes too loud the current is broken, and minute sparks are seen at the carbon point, and the jarring sound is heard at the same time in the telephone. The sound of a musical box is perfectly reproduced when the box is held in the air; the instrument is therefore sensible to sound-waves in air as in solids.

Rugby

Geo. M. SEabroke

I SEND an account of an experiment with the microphone which may interest some of your readers.

A microphone, made of three pieces of gas carbon (as described by Prof. Hughes) and the primary wire of a $\mathrm{Du}$ Bois Reymond's induction-coil, are placed in the circuit of a single Daniell cell. The wires from the secondary coil (pushed bome) are attached to the poles of a Lippmann's capillary electrometer. The Daniell and microphone are twenty-five feet distant from the clectrometer. If an observer watches the capillarytube and speaks or sings to the microphone (zwhich is twenty-five fect distant) definite and large movements of the mercury-column will be seen. The movements for various letters resemble those which have been previously observed to take place with the telephone, the "w" giving its curious double movement.

$$
\text { F. J. M. PAGE }
$$

Physiological Laboratory, University College, London

\section{EARTHQUAKE IN VENEZUELA}

$\mathrm{T}$ the evening of the I2th of this month a severe earth1 quake destroyed the town of Cua, in this country. Cua is situated on the left bank of the River Tuy, in $10^{\circ} 8^{\prime} 15^{\prime \prime}$ L. N. and $66^{\circ} 55^{\prime}$ W., Greenw. The height over the level of the Caribbean Sea I found in 1873, by barometrical measurement, 232 metres. It was the centre of a very flourishing agricultural district (annual produce, about $80,000 \%$. a year), and had about 3,000 inhabitants.

The weather had been for weeks exceedingly hot, as generally this year in Venezuela. At 5 o'clock in the afternoon, before the earthquake, a temperature of $100^{\circ}$ is said to have been noticed, and six days later, at the same hour, I observed myself $95^{\circ}$. The sky was clear, and the moon in perfect brightness. The shock occurred some minutes before a quarter to nine o'clock, and so violent was it that in less than two seconds all the centre of the town was a heap of ruins. It is impossible to fix the exact time of the shock, but it was felt in Carácas at $8 \mathrm{~h} .4 \mathrm{Im}$. 34s., the distance in a straight line between both places being about twenty-six English miles.

The centre of the town was situated on a small hill, about 20 metres over the lower part. The hill is com- posed of gneiss, micaceous and chloritic schists, rising rather steep towards W.S.W. This hill is surrounded by strata of clay and marl, covered by a deep stratum of alluvial soil, and resting on dark limestone and argillaceous schists, containing numerous crystals of iron pyrites.

Only the upper town was laid waste; the lower part suffered comparatively very little. From actual observations I found that the angle of emergence of the shock was about $60^{\circ}$. The centre cannot have been very deep, as the destruction was limited to a spot measuring only one square mile, although the shock of the transverse wave was felt in places Ioo miles distant. The soil had burst at different places, giving issue to water highly impregnated with sulphuretted hydrogen. The shocks continued for several days, and are not yet entirely gone, but no further damage has been caused. About 300 people were killed; the loss of property is said to be about $300,000 \%$. sterling.

I have reason to think that this earthquake bad nothing to do with volcanic forces, but was due to an interior subsidence or downfall of calcareous rock, as I intend to prove in a special memoir on this subject, as soon as I shall have visited the locality once more.

Carácas, April 30

A. ERNST

\section{OUR ASTRONOMICAL COLUMN}

TEMPEL'S COMET, I 873 , II.-We continue the ephemeris of this comet, for the latter half of June, as given by M. Schulhof in the Paris Bulletin International of May 7. If the calculated epoch of perihelion passage be approximately correct, the intensity of light will be increasing, and the comet would arrive at its least distance from the earth early in July. But the possible error in the mean motion determined from the observations of 1873 , may render a search over a wide extent of sky unavoidable, if the comet is to be recovered at the present return. Shortly before the completion of his calculations M. Schulhof informed the writer that the probable error in the mean daily motion would not exceed $\pm 7^{\prime \prime}$, but this degree of uncertainty involves a difference of nearly \pm 20 days in the date of perihelion passage, so that the comet may be found after close search in a position considerably distant from the computed one. As in other similar cases, if the observer has the command of an equatorially-mounted instrument of good aperture, the most promising plan of search will be to commence at the calculated declination for the day, extending the sweep to $30 \mathrm{~m}$. or $40 \mathrm{~m}$. on each side of the calculated R.A., and to continue the same proceeding for $3^{\circ}$ or $4^{\circ}$ on each side of the calculated declination. It may be remarked that the computed R.A. for a certain change in perihelion passage, varies more rapidly than the computed declination. Perhaps there is a greater probability of the comet being detected at the latter end of June than subsequently, if the weather is generally favourable for a careful search.

The following positions for Paris midnight are deduced on the assumption that the comet will arrive at perihelion Sept. I'5, the most probable date :-

\begin{tabular}{|c|c|c|c|c|c|c|c|c|c|c|c|}
\hline \multirow[b]{2}{*}{ June } & \multirow[b]{2}{*}{15} & \multicolumn{3}{|c|}{ Right Ascension. } & \multicolumn{3}{|c|}{$\begin{array}{l}\text { N. Declina } \\
\text { tion. }\end{array}$} & \multicolumn{3}{|c|}{$\begin{array}{l}\text { Distance from } \\
\text { earth. }\end{array}$} & $\begin{array}{l}\text { Intensity } \\
\text { of light. }\end{array}$ \\
\hline & & $\ldots$ & $\begin{array}{rl}\text { n. } & \text { m. } \\
\text { I } 5 & 34\end{array}$ & 44 & $\ldots$ & $\dot{5}$ & 6 & $\ldots$ & 0.667 & $\ldots$ & 0.90 \\
\hline , & I9 & $\ldots$ & 1532 & I5 & ... & 4 & I 7 & $\ldots$ & 0.659 & $\ldots$ & 0.95 \\
\hline , & 23 & $\ldots$ & I $53^{\circ}$ & 20 & ... & 3 & 20 & $\ldots$ & 0.654 & $\ldots$ & 0.99 \\
\hline & 27 & $\ldots$ & I5 29 & 5 & $\cdots$ & 2 & 15 & $\cdots$ & 0.651 & $\cdots$ & $10_{3}$ \\
\hline & I & $\ldots$ & 1528 & $3 I$ & $\ldots$ & I & I & $\ldots$ & 0.649 & $\ldots$ & 1.06 \\
\hline
\end{tabular}

THE RECENT TRANSIT OF MERCURY.-In the instructions for observing this phenomenon suggested by Prof. Newcomb, and circulated by the United States Naval Observatory, it is remarked that "its accurate observation is of especial importance as affording data 